\title{
PARTICIPATION OF CITIZENS IN THE CREATION OF PUBLIC SERVICES IN MAŁOPOLSKA AND PIACENZA
}

\author{
AGNIESZKA SZCZUDLIŃSKA-KANOS,${ }^{1}{ }^{1}$ ANUSZ SASAK, ${ }^{2}$ \\ EMANUELE ANTONIO VENDRAMINI ${ }^{3}$
}

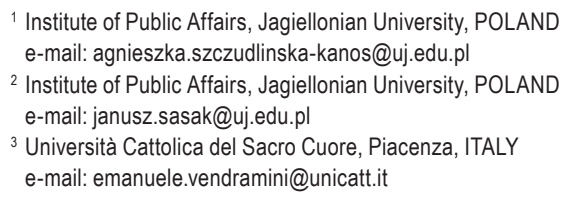

RECEIVED
ACCEPTED
JEL
CLASSIFICATION

KEYWORDS public services, self government, public management, planning in the public sector

ABSTRACT

3 July 2017

15 December 2017

R58, L88, H11
In recent years, the participation of citizens in public life plays an increasingly important role in the management, in particular in local government units at the local level. Changes in the needs and demands of citizens have led to the fact that social participation has effectively transformed itself into active, effective and multidirectional action. Local communities are becoming more aware of the fact that their active participation in public life, based on multilevel and multi-sectoral cooperation, depends on the quality of public services. The purpose of this paper is to show opportunities and different solutions of influence citizens on the shaping of public services in selected local governments units on the same level in Italy (Piacenza) and Poland (poviats in Małopolska).

\section{Introduction}

Nowadays, rapidly progressive socio-economic development caused that changed the expectations of citizens to services provided by the public services. In countries where democratic systems exist, there are numerous legal regulations and a broad set of instruments to oversee the proper performance of public authority tasks at various levels of activity. This control, which is a part of public management is institutionalized in the vast majority of cases 
and in recent years the need for social control has become more and more evident. The implementation of this control is possible, inter alia, through the use of tools ensuring effective cooperation between citizens and the public authorities. While direct co-operation between the public and central government is limited, it is possible and desirable at the local government level. Citizens should participate in the decision-making process, and the requirement for effective management in local self-government units is, firstly, equipping local communities with actual and authentic entitlements, and secondly, realizing their enormous role and impact.

It is therefore appropriate to check and demonstrate how local communities in Italy and Poland participate in the shaping of public services to which the local authorities are obliged in both countries. In the paper tried to show the different role of citizens in shaping local politics and analyzed the strategic planning process in Piacenza and Małopolska, where were taking into account the strategies for solving social problems, because the activity of local authorities in the social sphere, focused on problem solving, it includes the provision of certain services.

In the article there were used various methods and techniques of research. Inter alia there used the descriptive, comparative and tabular - descriptive method. There were analyzed documents and data in territorial self-government units and statistical data published by national institutions.

The article is the result of international pilot studies conducted jointly by universities Università Cattolica del Sacro Cuore and Jagiellonian University.

\section{International determinants of public participation}

The essence of participation in public affairs management is that public administrations, both governmental and local government, interact with the citizens through the use of specific participatory and consultative procedures (Hausner, 2008). The introduction of participation there are in favor of both ideological considerations (a reference to the democratic ideas) and practical considerations (increase effectiveness, improvement and adaptation of services) (see Ober, 2017). The key element of such governance is public participation, which has been recommended internationally at the international level (OECD, European Commission) since the 1990s. This participation includes four main forms of public participation in public life:

- public activity (actions initiated by local community members in the form of lobbing, protest, advocacy, civil disobedience),

- involvement of citizens (actions initiated by public authorities - for example in the form of public consultations);

- electoral participation (activities involving participation in elections and referendums), and

- compulsory participation (compulsory actions - for example paying taxes to a given community) (Kaźmierczak, 2011).

In Poland, from the point of view of influence on the current activities of the territorial unit and the provision of its public services, a key role plays engaging of citizens and electoral participation. In Italy only electoral participation contributes to shaping services at the local level, and citizens rather are not interested in directly influencing the shaping of local strategy documents.

It is worth emphasizing that the involvement of citizens in public life in specific countries depends on a number of issues, including: cultural nature (the willingness of the society to co-manage), economic (specific financial resources), political (openness to cooperation with citizens and acceptance of certain forms of cooperation with Authority side) and technical (established rules and procedures) (Zybała, 2013). 


\section{Citizen participation in shaping public services in poviats of Małopolska}

There are many forms of direct or indirect participation in the Polish legal system, including information; consultation, including participatory budget institutions or civic initiative adopt resolution; delegation; cooperation, local initiative, and of course the general elections and local referendas (see Dobrowolski, Kożuch, Pypłacz, Sasak, Szczudlińska-Kanoś, Žukovskis, 2016). It should be emphasized that the selection of the above mentioned solutions, even despite the lack of regulatory work in the part of local governments on the basis of statutes, regulations, or various other regulations, agreements and their practical use is characterized by great diversity.

Talking about citizen involvement in public management, it is important to address to the issue of local strategy documents, which are increasingly influenced by the opinions of local community members. In Poland, one of the strategic documents that is compulsory at the local level is a strategy for solving social problems. Mandatory creation of this type of strategy has been imposed by the legislature and results in the implementation of a number of legal acts, which should include in particular the Act of 12 March 2004 on social assistance (see SzczudlińskaKanoś, 2015).

For the purposes of this article, authors have analyzed the strategies of solving the social problems functioning in all 22 poviats of Małopolska (19 poviats and 3 cities with poviat rights). Preliminary analysis of the documents showed that such strategies were developed in all self government units, although some documents were developed after the deadline. The main reason for the above was the prolonged participatory character of the whole process. The carried out analyzes showed that the documents, despite the absence of repeated references corresponded with the strategic documents developed at higher levels - regional, national and international level. The analysis shows that the diagnostic part of the strategies is to a large extent elaborated. Its content fluctuates between $40 \%$ to almost $90 \%$ and covers an average of $76 \%$ of the document. The goals of the district strategies for solving social problems in Małopolska are different, as are the diagnoses presented in them. In the strategies there declared that the selection of priority areas was the result of an analysis of the current social situation of poviats, although most often elaborated on the basis of quantitative data, external environment analysis and statutory requirements. In general, the issues in the strategies concerned: broadly understood support for families, particularly those at risk of exclusion, foster families, inadequate care and education; childcare; help the elderly and the disabled; promotion of employment; professional activation; and strengthening the cooperation of entities implementing social policies of poviats.

In $64 \%$ of the poviats, at the declarative level, there appeared the participation of representatives of public and non-governmental institutions. In the $30 \%$ of the poviats during the preparation of the strategy there were organized the workshops, where participated the representatives of the local government representatives, the representatives of the social welfare and labor market institutions, the representatives of the Police, the organizations of the third sector and possibly the social leaders.

Only $21 \%$ of the poviats declared co-creation of the strategy with the inhabitants. Only two of them indicated the form of consultation, which was the questionnaire delivered to residents through social assistance centers and non-governmental organizations. This polls were also posted on the website. It should also be noted that the share of inhabitants in the process of creating strategies more frequently appeared in newer strategies. As many as $77 \%$ of the strategies that indicated the participation of members of the community were developed after 2014. This fact would have a negative impact on the quality of the strategy, because the lack of contact with the inhabitants has in principle prevented the identification of new social problems and also increased the likelihood that the adopted 
documents do not fully correspond to the actually existing needs, so the local government units will not be testified to suit the needs of residents of public services.

Participation of Italian citizens in shaping public services looks very different. Citizens only have an indirect influence on the creation of strategic documents in local governments, as exemplified by the strategic planning process described below in Piacenza.

\section{The strategic planning process of the ltalian local governments: the case of the province and the city of Piacenza}

In 2011 the Italian Central Government passed a reform (Sicilia, Steccolini, 2017) on local governments. A new managerial tool was introduced: the unique document of planning (DUP in Italian) (Bleyen, 2017). Previously Italian local governments were used to produce many different documents aimed at planning and programming and linking the priorities with the budget. With the 2011 reform all the municipalities had to implement the same document with the same structure and the same aims. It is a 3 years document with a rolling process so each each a new period is added (2017-2019 document approved in 2016 becomes the 2018-2020 in 2017 and so on in the forthcoming years).

The DUP represents the framework and the linking pin with all the other managerial documents the Italian municipalities have to produce (e.g. budget, Performance plan) and it is strictly linked to the with the political agenda of the Mayor. In Italy before the election each candidate has to produce a document that represent the agenda for his/her government in case he/she should win the election. The DUP is made of two sections: the strategic and the operative parts. The strategic part presents the Key performance areas of the municipality for the next three years while the operative one address the implementation plans so to translate the strategy into actions. The DUP has to be approved by the city council yearly and it usually presents in its first part a SWOT analysis of the local government. The DUP and specifically the operative part represents the long term objectives and the priorities of the municipality and it is linked to two managerial tools the annual budget and the performance plan. The annual budget allocates the financial resources to the different actions for that specific year with the performance plan cascades the organizational objectives internally at unit and at personal level too.

In Italy all the public managers are given annual goals (financial and non financial goals) linked to the DUP and to the annual budget. If the individual targets are met financial incentives are given to the managers. Each single municipality has an independent body appointed for three years (renewable) in charge of measuring the individual and the overall performance of the organization (yearly production of a performance report).

Table 1. Strategic planning in Italian local governments

\begin{tabular}{llcc}
\hline \multicolumn{1}{c}{ Document } & \multicolumn{1}{c}{ Aim } & Duration & Approved by \\
\hline DUP & Strategic planning & 3 years rolling & City council \\
\hline Performance plan & $\begin{array}{l}\text { Programming and cascading internally the annual goals } \\
\text { on the first year }\end{array}$ & 3 years rolling & Mayor and his/her delegates \\
\hline Performance report & Performance measurement & 1 year & $\begin{array}{l}\text { Indipendent body produces it and then } \\
\text { it is acknowledge by the Majoyr }\end{array}$ \\
\hline
\end{tabular}

Source: own study. 
According with the Italian law all these documents have to be uploaded on the local municipality website. In this paper it will be analyzed the case of the City of Piacenza, a municipality of 102,000 inhabitants, place in the northern part of Italy and specifically in the EMILIA ROMAGNA Region. It is located by the Po river and it was founded by the Romans in the $3^{\text {rd }}$ Century B.C.

The 2017-2019 DUP (the document aimed at managing the strategic planning process for the Italian municipalities) has been approved by the City Council on Sept $12^{\text {th }} 2016$. It is structured according with the 2011 law and divided in to parts: the strategic and the operative ones.

The strategic part presents a SWOT analysis of the City and strategic Goals. They are 11:

1. Economic Development for competitive City.

2. Innovation, research and university for a smart.

3. Health care, solidarity and social cohesion for a friendly city.

4. Environment for a sustainable city.

5. Mobility for a interconnected city.

6. Safety for a peaceful city.

7. Young generations and educational system for the city of the future.

8. Culture, tourism, free time and sport for educated city for the active city.

9. Protection and development of the territory for an attractive city.

10. Active citizenship and social inclusion for a engaged city.

11. Serving the communities for an efficient city.

Each of these strategic goals is then in detail described.

The last point of the strategic part is related to transparency and on the how the local government of Piacenza will report to the citizenship. The DUP clearly states that the social reporting will be twofold: annually with the discussion of the city council on the performance and right before the new election day with the final document produced by the administration in charge (strategic control). The operative part takes into consideration each single strategic objective describing how are in charge of implementing it, which are the involved stakeholders and which are the missions and the actions/programs to be implemented in the next three years. At the end of this part the DUP presents the budgeting system for the forthcoming years in term operating and capital expenditures and operating and capital revenues. This is aimed at linking the strategic goals, the strategic objectives and the action plans with the resources available and allocated. After having presented the content and the structure of the DUP, the new strategic planning tools implemented by the Municipality of Piacenza and for all the Italian local governments by the 2011 reform it is important to analyze the pros and cons of this managerial tool. As all the managerial tools it is neutral by definition it can be used in order to help managing the city or just in a bureaucratic way.

In term of transparency the documentation is uploaded on the city website (it is the law) but if the question is: will the citizens ever read it? The answer is no, it is a 301 pages long document, none will ever read it. It has internal purposes, managerial and political purposes, city managers and politicians are familiar with that document, the citizenship is not even aware of the existence of it; but it is available on the web. Each single municipality has its DUP posted on its website within the transparency folder. So the tool is there but the population is not engaged not aware and, perhaps not even able to understand that document. The average Italian citizen does not understand the different between a goal and an objective, and objective and a measure, a measure and its target. So from a managerial perspective this is way all these documents have to be approved by the city council and the discussion 
will never get published or televised by the local media because the citizens are not interested nor involved if not indirectly through their representative: the city councilmen/women.

\section{Conclusions}

From the above analysis it is clear that the influence of citizens on shaping public services in local governments in Poland and in Italy is clearly different. In Italy, the dominant form of governance is indirect democracy, otherwise called a representative, where citizens do not directly participate in the drafting of strategic documents, and their expectations are expressed primarily by voting in elections and through greater control of the authorities. In Poland over the last decade there has been an increase in public interest in public affairs. Communities see the need to co-decide on the quality and quantity of local public services and are more likely to be involved in the creation of strategic documents, although they are not always able to. It is therefore necessary to strengthen and regulate any direct forms of participation of citizens.

Finally, it is worth emphasizing that the study carried out by the Institute of Public Affairs shows that, from the point of view of participation in Poland, it is important that the services are universal and concern the general public and that they are selective and satisfy only specific needs, solve specific problems. It turns out that the type of services affects the level of participation (see Kaźmierczak, 2012). Using public services is not motivating for participation unless an initiative in this area comes from the service provider. Attendance in participation increases with individualization of services.

The pilot studies and conclusions drawn from them should be a contribution to their continuation. However, studies should be conducted with due diligence of statistical representativeness.

\section{References}

Bleyen, P., Klimovský, D., Bouckaert, G., Reichard, C. (2017). Linking budgeting to results? Evidence about performance budgets in European municipalities based on a comparative analytical model. Public Management Review, 7 (19), 932-953.

Dobrowolski, Z., Kożuch, A.J., Pypłacz, P., Sasak, J., Szczudlińska-Kanoś, A., Žukovskis, J. (2016). Participation as a management tool in local government units. Scientific Society of Contemporary Management and Business and Rural Development Management Institute Kraków, Kowno.

Hausner, J. (2008). Zarządzanie publiczne. Warszawa: Wydawnictwo Naukowe Scholar.

Kaźmierczak, T. (2011). Partycypacja publiczna: pojęcie, ramy teoretyczne. In: A. Olech (ed.), Partycypacja publiczna. O uczestnictwie obywateli w życiu wspólnoty lokalnej (pp. 84-99). Warszawa: Instytut Spraw Publicznych.

Kaźmierczak, T. (2012). Udział mieszkańców gmin w zarządzaniu gminnymi usługami publicznymi. In: A. Olech (ed.), Dyktat czy uczestnictwo. Diagnoza partycypacji publicznej w Polsce, Tome I (pp. 92-103). Warszawa: Instytut Spraw Publicznych.

Ober, J. (2017). Demopolis: democracy before liberalism in theory and practice. Cambridge: Cambridge University Press.

Sicilia, M.F., Steccolini, I. (2017). Public Budgeting in Search for an Identity: State of the Art and Future Challenges. Public Management Review, 7 (19), 90-95.

Szczudlińska-Kanoś, A. (2015). Participatory democracy to the contemporary problems of Polish social policy. World Academy of Science, Engineering and Technology International Journal of Humanities and Social Sciences, 6 (9), 1988-1994.

The Act of 12 March 2004. On social assistance. OJ 2004 No. 64 pos. 593.

Zybała, A. (2013). Warunki dobrej partycypacji. Animacja Życia Publicznego. Zeszyty Centrum Badań Społeczności i Polityk Lokalnych, $2(9)$.

Cite this article aS: Szczudlińska-Kanoś, A., Sasak, J., Vendramini, E.A. (2018). Participation of citizens in the creation of public services in Małopolska and Piacenza. European Journal of Service Management, 2 (26), 251-256. DOI: 10.18276/ejsm.2018.26-31. 